\title{
From Scroll to Codex: Dynamics of Text Layout Transformation in the Hebrew Bible
}

\section{The Adoption of the Codex in Judaism}

We know very little about the process by which late-antique and early-medieval Jewish communities adopted the codex for copying and transmitting their fundamental texts (for more on these matters, see the chapter in this volume from Outhwaite). This is due mainly to the fact that there is a long hiatus during which we have very few texts written in Hebrew, between the second century of the Common Era - the date of the latest scrolls and the documents found in several places around Qumran and the Dead Sea ${ }^{1}$ - and the ninth and tenth centuries, ${ }^{2}$ the date of the first more or less complete Bible codices that are extant today, which were copied in Palestine, Syria, Egypt, Iraq, and Iran. ${ }^{3}$ There are many reasons that

1 For detailed palaeographical dates for the different groups of documents from the Judaean Desert, ranging from the third century BCE to the second century CE, see Emanuel Tov, Scribal Practices and Approaches Reflected in the Texts Found in the Judean Desert, STDJ 54 (Leiden: Brill, 2004), 5-6. See also Chapter 1 in this volume.

2 There is only a very small number of Bible fragments that can be dated with certainty to before the ninth century CE. See Judith Olszowy-Schlanger, “The Hebrew Bible," in The New Cambridge History of the Bible, vol. 2, From 600 to 1450, ed. Richard Marsden and E. Ann Matter (Cambridge: Cambridge University Press, 2012): 19-40, esp. 20, and Colette Sirat, Hebrew Manuscripts of the Middle Ages (Cambridge: Cambridge University Press, 2002), 27-29 and 34-36.

3 The oldest dated codex, now lost, is that of the Prophets from the Karaite Mussa Dar'i Synagogue in Cairo, which had a colophon that mentioned the date corresponding to 894/895 CE. Nonetheless, there is some doubt about the authenticity of the colophon, and some scholars date the codex a century later, i.e., at the end of the tenth century or beginning of the eleventh. Cairo Geniza fragments of a Bible codex copied in Gunbad-i-Mallgàn (Iran) are dated with certainty to 903/904 CE. See Malachi Beit-Arié, Colette Sirat, and Mordechai Glatzer, Codices hebraicis litteris exarati quo tempore scripti fuerint exhibentes - Otsar ha-mitshafim ha-ivriyim: kitve-yad bi-khetav ivri mi-yeme ha-benayim be-tsiyune ta'arikh., vol. 1, Jusqu'à 1020, Monumenta Paleographica Medii Aevi. Series hebraica (Turnhout: Brepols, 1997), § 1-2 (pp. 25-41).

Note: Research on this topic is possible thanks to the collaborative research project entitled "Legado de Sefarad II. La producción material e intelectual del judaísmo sefardí bajomedieval," which is based at the ILC-CSIC in Madrid and funded by the Plan Nacional de I+D+i (FFI201563700-P).

Ә Open Access. (c) 2020 Javier del Barco, published by De Gruyter. @)BY-NC-ND This work is licensed under a Creative Commons Attribution-NonCommercial-NoDerivatives 4.0 International License.

https://doi.org/10.1515/9783110634440-006 
have been suggested for this hiatus, ${ }^{4}$ but none of them provides any details about when or how Jews began to adopt the format of the codex for copying texts in Hebrew. Nevertheless, there are two widely accepted ideas about the adoption of the codex by Jewish communities. One is that, during the early centuries of Christianity, the codex was largely rejected since it was the main format in which Christian religious texts circulated. ${ }^{5}$ The second is that the codex was not adopted until after the spread of Islam, ${ }^{6}$ following the assimilation of the Eastern Jewish communities into the new dominant culture, particularly the practices of Islamic book production, which used the codex as its main format. ${ }^{7}$

What we do know is that, as the codex was being adopted, both the horizontal and the vertical scroll (rotulus) continued to be used, and the different functions and kinds of texts conveyed by each were not fixed definitively until at least the eleventh century CE. Thus, vertical scrolls, or rotuli, were frequently used up to that date to transmit different kinds of texts, as Judith Olszowy-Schlanger has shown. ${ }^{8}$ The horizontal scroll, which was the format used going back to ancient times, gradually became specialized for transmitting the sacred text used for liturgical purposes in the synagogue. In this way, the ritual reading of the Pentateuch, as well as other sections of the Hebrew Bible, was performed using scrolls produced and copied according to strict rules drawn from traditional rabbinical literature. This functional specialization of the scroll continues to this day in traditional synagogue liturgy as a fossilized remnant of a format passed down from antiquity. However, even if the scroll continues to be used, the fact is that, beginning sometime between the seventh and the ninth centuries CE, Eastern Jewish

\footnotetext{
4 One possible reason has to do with the fact that the teaching of the text of the Bible was an eminently oral activity during this period. See David Stern, "The First Jewish Books and the Early History of Jewish Reading," JQR 98/2 (2008): 163-202, esp. 178-81; “appreciating the fact that the rabbis' knowledge of the Bible was acquired from auditory experience, we can better understand certain features of midrash that otherwise are largely inexplicable" (180).

5 See Irven M. Resnick, “The Codex in Early Jewish and Christian Communities,” Journal of Religious History 17/1 (1992): 1-17, and Sirat, Hebrew Manuscripts of the Middle Ages, 35.

6 Other than a doubtful reference by Saint Augustine to the use of codices by Jews, the first mention comes from the Islamic period, in the eigth century. See Judith Olszowy-Schlanger, "The Anatomy of Non-Biblical Scrolls from the Cairo Geniza," in Jewish Manuscript Cultures: New Perspectives (Berlin: De Gruyter, 2017): 49-88, esp. 52, and Sirat, Hebrew Manuscripts of the Middle Ages, 35.

7 François Déroche, Manuel de codicologie des manuscrits en écriture arabe, Études et recherches (Paris: Bibliothèque nationale de France, 2000), 13.
}

8 Olszowy-Schlanger, "The Anatomy of Non-Biblical Scrolls," esp. table 1, pp. 55-61. 
communities largely adopted the codex, even though the new format coexisted with other, preexisting forms such as horizontal scrolls, rotuli, and pinkasim. ${ }^{9}$

Indeed, the transition from the scroll to the codex took place gradually over a long period, and during this process all formats continued to be used. The rotuli that have been mentioned, as well as fragments of horizontal scrolls from the Cairo Geniza, lead us to question the traditional hypothesis that the scroll was rapidly replaced by the codex, except in the liturgical context, ${ }^{10}$ and that therefore many of these fragments should be dated to before the Islamic conquest. As Olszowy-Schlanger asserts, "different book forms co-existed in the non-biblical sphere for much longer than previously believed."11 Therefore, only an exhaustive codicological and paleographic analysis of the scroll fragments can provide a dating that is not based on traditional, a priori assumptions, which should be rejected.

One of the most useful aspects of a formal comparative analysis for understanding the dynamics of the transition from the scroll to the codex is the text layout used for the Bible in the two formats. The term "text layout" is mostly concerned with the planning of the pages in a codex or sheets in a scroll where a text is to be copied, including the organization of spaces and the choice of typographical features, before the text is copied. P. Andrist, M. Maniaci, and P. Canard have recently defined text layout as follows:

L'ensemble des stratégies que le copiste (éventuellement en collaboration avec d'autres artisans) met en œuvre pour distribuer un contenu sur l'ensemble des pages destinées à l'accueillir, de façon à le rendre correctement (et aisément) accessible à ses lecteurs.

[The set of strategies that the copyist (possibly in collaboration with other craftsmen) implements to distribute a text on all the pages intended to accommodate it, so as to render it correctly (and easily) accessible to its readers. $]^{12}$

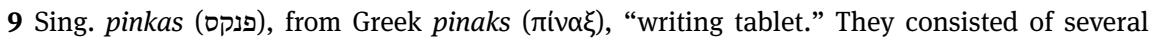
tablets attached altogether, i.e., each tablet attached to the ones that preceded and followed it, in a concertina-like way. They were used for jottings and ephemera, and are mentioned in the Mishnah. See Olszowy-Schlanger, "The Anatomy of Non-Biblical Scrolls,” 51.

10 See Israel Yeivin, Introduction to the Tiberian Masorah, trans. E. J. Revell, Masoretic Studies 5 (Missoula, Montana: Scholars Press, 1980), § 5 (p. 7): “The scroll was the only accepted format for a Jewish book until the end of the Talmudic period (c. 600 CE) ... The codex form ... does not seem to have been used until about $700 \mathrm{CE}$. As commonly occurs, the older form continued to be used for religious purposes."

11 Olszowy-Schlanger, "The Anatomy of Non-Biblical Scrolls," 54.

12 Patrick Andrist, Paul Canart, and Marilena Maniaci, La syntaxe du codex: Essai de codicologie structurale, Bibliologia: elementa ad librorum studia pertinentia 34 (Turnhout: Brepols, 2013), 58. 
It is important to point out that the concept of text layout is not tied to the organization of a specific page but rather affects a group of pages (or sheets) on which a textual unit is arranged. Thus, the choices - or requirements - for the size of the text, the script type and mode, the placement of certain words or phrases, and the hierarchization of texts are among the text layout strategies and do not depend at least not solely - on the organization of the writing space on one specific page.

Therefore, in this chapter I am going to focus on the dynamics behind the transformations in text layout in Bible manuscripts that accompanied the transition from scroll to codex, as a way to understand how the text layout specifications conceived and codified for the copying of Bible scrolls were transformed and adapted for the copying of Bible codices. We will look closely at how the implementation of these specifications, which rabbinic literature had already standardized, is negotiated with different factors that will transform the end product in the codex. Among these factors are the adaptation to a new spatial unit for copying - the page; the degree of faithfulness in codices to the norms established for copying the text of the Bible in scrolls; factors related to geo-cultural traditions (that is, aspects of the text layout that vary according to the geo-cultural area in which the codex was copied: Ashkenaz, Sepharad, Italy, Byzantium, the Orient) ${ }^{13}$; and lastly, aesthetic factors related to the particular time period when the copy was made (the fashion of the day) or the tastes of the commissioner or the scribe.

\section{Copying Torah Scrolls: Transmission and Tradition}

The text layout specifications conceived for copying Bible scrolls are codified in several places in the rabbinical literature (both Babylonian and Palestinian Talmudim, Massekhet Soferim), as well as in certain works by medieval authors who gradually established the details of these specifications, notably Maimonides (1135-1204), Meir Abulafia (1170-1244), and Menahem ha-Meiri (1249-1310). Specifications regarding the text layout of Hebrew Bibles that affect the resulting page layout in a codex include the following:

13 For codicological Jewish geo-cultural areas, see Malachi Beit-Arié, Hebrew Codicology: Tentative Typology of Technical Practices Employed in Hebrew Dated Medieval Manuscripts (Paris: Institut de recherche et d'histoire des textes, 1977), 17. 
- The בי"ה שמ"r rule, according to which the following words should be copied at the beginning of a column: בראשית ("In the beginning," Gen. 1:1), יהודה ("Judah," הבאים ("that came," Exod 14:28), שמר ("Observe," Exod 34:11), מה טובו ("How goodly,” Num 24:5), and ואעידה ("and I will call to witness,” Deut 31:28) ${ }^{14}$;

- The distinctive features of some letters ${ }^{15}$;

- The use of blank spaces and lines in open and closed sections (petuhot and setumot) ${ }^{16}$ and at the end of each book, and to divide the text into pericopes (parashiyyot) and other paragraph divisions ${ }^{17}$;

- The layout of the text in the poetic sections of the Bible and in the poetic books (Sifre EMeT) - Job, Proverbs, and Psalms. ${ }^{18}$

The specifications relating to the layout of the poetic sections are particularly relevant, since even though they do not need to be followed in codices, many of them will be adhered to, and they will pose many challenges for transposing the text to the codex format.

In $b$. Meg. 16b, a mention of the text layout for the list of the sons of Haman (Esth 9:7-9) in the copying of the Esther scrolls declares

All the songs are written in the form of a half brick over a whole brick, and a whole brick over a half brick, with the exception of this one [the list of the sons of Haman] and the list of

14 Yeivin, Introduction to the Tiberian Masorah, § 75 (p. 43), mentions that there was some disagreement regarding these words, and therefore the convention was not always followed in codices.

15 Christian D. Ginsburg, Introduction to the Massoretico-Critical Edition of the Hebrew Bible (New York: Ktav Publishing House, 1966), 318-45, lists the following: the fifteen extraordinary points, suspended letters, and inverted nuns. Yeivin, Introduction to the Tiberian Masorah, $\S 79$ to $\S 86$ (pp. 44-48), mentions dotted words, inverted nun, suspended letters, large letters, small letters, and other unusual letter forms. See also Manfred R. Lehmann, "Further Study of the Pe'in Lefufot," in Proceedings of the Eleveenth Congress of the International Organization for Masoretic Studies (IOMS), Jerusalem, June 21-22, 1993, ed. Aron Dotan (Jerusalem: World Union of Jewish Studies, 1994): 41-46. He lists the distinctive features as follows: "Extraordinary Points, Isolated Letters, Suspended Letters, Large and Small letters, and Other Odd Letters such as the waw with a crack in the middle, the crooked nun, and the 'winding peh' [peh lefufah]" (41). On the use of large letters in particular, see María Josefa de Azcárraga, "Las 'ôtiyyôt gedôlôt en las compilaciones masoréticas," Sefarad 54/1 (1994): 13-29.

16 The sections or paragraphs that the pericopes (parashiyyot) of the Pentateuch are divided into are named - petuhah ("open") and setumah ("closed") - for how the blank space between the end of one section and the beginning of the next should look. See Yeivin, Introduction to the Tiberian Masorah, § 74 (pp. 40-41).

17 Yeivin, Introduction to the Tiberian Masorah, $\S 72$ to $\S 75$ (pp. 39-43).

18 Yeivin, Introduction to the Tiberian Masorah, §77 (pp. 43-44). See below. 
the Kings of Canaan (Josh. 12:9-24), which are written in the form of a half brick over a half brick, and a whole brick over a whole brick. ${ }^{19}$

This mention is important, because it establishes two kinds of formats for poetic sections of the Bible. On the one hand we have "the form of a half brick over a half brick, and a whole brick over a whole brick," that is, lines in which the words line up one above the other, leaving blank spaces in between that also line up one over the other (Fig. 1). This is the arrangement of the text containing the list of the sons of Haman and the text containing the list of the kings of Canaan:

Fig. 1: Layout 1: A half brick over a half brick, and a whole brick over a whole brick.

On the other hand, there is "the form of a half brick over a whole brick, and a whole brick over a half brick," in which the words and spaces alternate from one line to the next (Fig. 2):

Fig. 2: Layout 2: a half brick over a whole brick, and a whole brick over a half brick.

This second arrangement is the one that, according to $b . M e g .16 \mathrm{~b}$, the rest of the poetic sections of the Bible should adopt, including the Song at the Sea (Exod 15) and the Song of Moses (Deut 32) in the Pentateuch and the Song of Deborah (Judg 5) and the Song of David (2 Sam 22) in the Prophets. However, this typical arrangement of alternating bricks, or "brick pattern," is not the only arrangement

19 English translations of $b$. Meg. are taken from David Kantrowitz, The Soncino Talmud, version 3.0.8 (Davka Corp. and Judaic Press, 2004). 
found in medieval codices for all the poetic texts. Other arrangements of the text can be found for the poetic sections other than the brick pattern and, within the Pentateuch, there are arrangements that differentiate the Song at the Sea from the Song of Moses. Massekhet Soferim, one of the Minor Tractates of the Babylonian Talmud, prescribes a more specific arrangement of the text for the Song of Moses, the Song at the Sea, and the Song of Deborah. In chapter 12, it states

\begin{abstract}
A mnemonic sign for the beginnings of the lines [of the Song of Moses] is the following [it gives the first word in every line, the total number of lines being seventy] ... The Song at the Sea and the Song of Deborah are written in the form of a half-brick over whole brick, and a whole brick over half-brick. The Song at the Sea consists of thirty lines [it gives the first word in every line]. ${ }^{20}$ The mark for the Song of Deborah is sixty-four lines [it gives the first word in every line]. ${ }^{21}$
\end{abstract}

It seems that, according to Massekhet Soferim, the arrangement of the text in a brick pattern would apply only to the Song at the Sea and the Song of Deborah, since no specific prescription is provided concerning the layout of the Song of Moses. Only a list is given with the words that should be placed at the beginning of each line. By counting these line beginnings, we can deduce that the Song of Moses should be arranged in seventy lines, plus two additional blank lines, one coming before the poem and the other after it, as is indicated in the same chapter: "[The Song of Moses] must also be provided with the space of a full line above it and of a full line below it."22 Despite these details, Massekhet Soferim does not specify any other requirements pertaining to the text layout that should be used for the Song of Moses. Neither does it include that poem in the same group with the Song at the Sea and the Song of Deborah, for which it does specify an arrangement of the text following the well-known brick pattern. We can conclude, therefore, that for Massekhet Soferim the Song of Moses should be arranged in scrolls differently than the other two poems, as was customary, for example, in the medieval Sephardi tradition.

In chapter 13, Massekhet Soferim mentions what is described as the most common practice followed by scribes when copying the text of the Song of David and the poetic books of Psalms, Job, and Proverbs: "A skilled scribe," it states, "spaces [the lines] out symmetrically according to the beginnings, the middle

20 In Massekhet Soferim, the first word in line 30 is ("waters"), from את מי הים ("waters of the sea") in Exod 15:19. This is not the tradition mentioned by Maimonides. See below.

21 English translations of Massekhet Soferim are taken from Abraham Cohen, ed., HebrewEnglish Edition of the Babylonian Talmud: Minor Tractates (London: Soncino Press, 1948).

22 The practice of leaving blank lines before and after the poem is also used in the text of the Song at the Sea. 
pauses, and the endings of the verses." This would result in an arrangement of the text in which each verse would be divided symmetrically in two parts (Fig. 3):

Fig. 3: Layout 3: Divided symmetrically in two parts.

This layout, with secondary variations, is characteristic, for example, of the books of Psalms, Job, and Proverbs in the medieval Sephardi manuscript tradition. However, this prescription is far from being universally followed in medieval codices of the Bible for the Song of David.

The prescription given in y. Meg. 3:7 is very similar to what we have just seen in Massekhet Soferim. It establishes that "the Song at the Sea and the Song of Deborah are written in the manner of setting bricks, that is, two halves of a brick over a whole brick, and a whole brick over half-bricks," and it adds - like Massekhet Soferim 13, and also like b. Meg. 16b - that "the names of the ten sons of Haman and the Kings of Canaan are written with a half-brick over a half-brick and a whole brick over a whole brick, for no building could stand if built that way."23 It says nothing, however, about the copying of other poetic sections such as the Song of Moses or the Song of David.

Maimonides, in his Mishne Torah, Hilkhot Sefer Torah, defines the arrangement of the text of both the Song at the Sea and the Song of Moses according to the Ben Asher tradition. ${ }^{24}$ Maimonides had access to this tradition in Egypt by consulting authoritative Masoretic codices, which he claims to have used for a copy he himself made of a Torah Scroll. ${ }^{25}$ According to him:

23 English translations of $y$. Meg. are taken from Jacob Neusner, trans., The Talmud of the Land of Israel: A Preliminary Translation and Explanation, vol. 19, Megillah, Chicago Studies on the History of Judaism (Chicago, London: The University of Chicago Press, 1987).

24 Aaron b. Moses ben Asher and Moses b. David ben Naftali are considered the last two Masoretes of the school of Tiberias. See Yeivin, Introduction to the Tiberian Masorah, § 154 (p. 141), and Ângel Sáenz-Badillos, A History of the Hebrew Language (Cambridge: Cambridge University Press, 1996), $\S 4.5$ (pp. 105-11). For Masorah and Masorete, see below.

25 “... the scroll [meaning the codex] well known in Egypt containing the twenty-four books, which was in Jerusalem until recently, and which was used to check other scrolls. All relied on it, since Ben Asher corrected it ... I relied on it when I wrote a correct Torah Scroll.” Maimonides, Mishne Torah: Sefer Ahavah, Hilkhot Sefer Torah, chap. 8. English translation in Menahem 
This is the form of the poem Ha'azinu (The Song of Moses): every line has a blank space in the middle, like the shape of a closed paragraph, so that every line is divided in half. It is to be written in 70 lines. ${ }^{26}$ Here are the words at the beginning of each line [the list of words follows, which is the same as the one given in Massekhet Soferim]. ${ }^{27}$

This means that for Maimonides the Song of Moses is to be copied with a layout very similar to that of the list of the sons of Haman and the list of the kings of Canaan (Fig. 1). Concerning the Song at the Sea, he sets out the following:

The Song at the Sea is written in thirty lines. The first line is normal [i.e., there are no blank spaces in the line], while the rest are as follows: one line has an empty space in the middle, while the next line has two empty spaces, so that the line is divided into three and so that there is space opposite each written part, and writing opposite each space. ${ }^{28}$

Immediately after, as can be seen in a copy of the Mishne Torah corrected according to Maimonides's original, ${ }^{29}$ he offers the text of the poem in the form that it should take when copied. Maimonides not only takes up the ancient tradition of laying the text out in a brick pattern (Fig. 2) but also specifies the number of blank spaces that each line should have, one in one line, starting with line 2, and two in the next, and so on (Fig. 4).

Kellner, trans., The Code of Maimonides: Book Two; The Book of Love, Yale Judaica Series 32 (New Haven: Yale University Press, 2004), 100. It is interesting that Maimonides is copying a Torah Scroll from a codex ("the scroll... containing the 24 books" was without a doubt a codex, as no scroll contained the twenty-four books), thus reflecting a practice that persisted throughout the Middle Ages; see below.

26 The number of lines in medieval manuscripts of the Hebrew Bible varies between 67-73, according to different traditions of dividing the text into lines, 70 being the rule observed by Maimonides. The Aleppo Codex (Jerusalem, Makhon Ben Tzvi, MS 1), dated ca. 930 CE, arranges the Song of Moses in 67 lines. The Leningrad Codex (St. Petersburg, National Library of Russia, MS EBP. I B 19a), dated to 1008, arranges this song in 37 lines, each line roughly corresponding to two lines in codices presenting the text in 67-73 lines, except for the last line $(36 \times 2+1=73)$. See descriptions of both codices in Beit-Arié, Sirat, and Glatzer, Codices hebraicis, $\S 6$ and 17 (pp. 65-72 and 114-31).

27 Kellner, The Code of Maimonides: Book Two; The Book of Love, 101.

28 Ibid., 101-2.

29 Oxford, Bodleian Library, MS Hunt. 80. Copied in Egypt (Fostat?), between 1181 and 1204. See Adolf Neubauer and A. E. Cowley, Catalogue of the Hebrew Manuscripts in the Bodleian Library and in the College Libraries of Oxford, 2 vols. (Oxford: Clarendon Press, 1886-1906), and Malachi Beit-Arié, R. A. May, and Adolf Neubauer, Catalogue of the Hebrew Manuscripts in the Bodleian Library: Supplement of Addenda and Corrigenda to Vol. 1 (A. Neubauer's Catalogue) (Oxford: Clarendon Press, 1994), no. 577. 


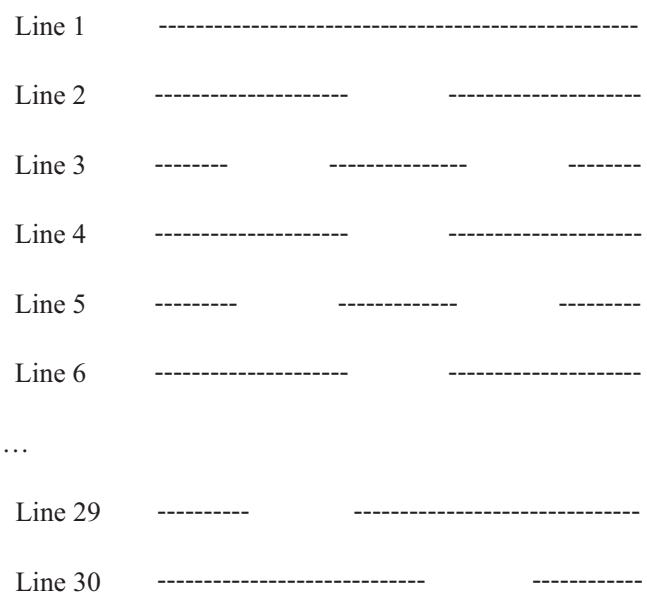

Fig. 4: Layout 4: Layout of The Song at the Sea as described by Maimonides.

As for lines $29-30,{ }^{30}$ Maimonides does not give any direct indication about how they should be copied, but the model of the poem as presented in the Mishne Torah manuscript displays lines 29-30 with one space each, line 29 with a space towards the end, and line 30 with a space towards the beginning (Fig. 4). This is the tradition followed by most medieval Eastern codices of the Hebrew Bible. ${ }^{31}$

In addition to these guidelines, Maimonides mentions other scribal practices that also concern the text layout of the Song at the Sea and the Song of Moses:

Other practices not mentioned in the Talmud, which scribes customarily do according to their traditions: that the five lines preceding the Song at the Sea begin with the words היבים ; that the five lines following the Song at the Sea begin with the

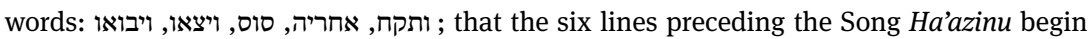

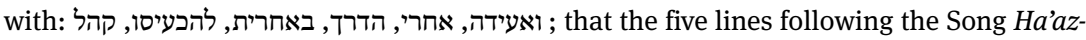

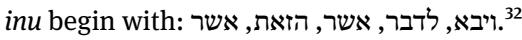

30 Lines 29 and 30 are the most unstable with respect to their form and to the distribution of text. Different traditions and regional variants can be traced through the Middle Ages. See Michèle Dukan, La Bible hébraïque: Les codices copiés en Orient et dans la zone séfarade avant 1280, Bibliologia: elementa ad librorum studia pertinentia 22 (Turnhout: Brepols, 2006), 46-49. 31 The first word in line 30 according to Maimonides is את מי הים ("waters of the sea"), in Exod. 15:19. This tradition is also followed in almost all medieval Eastern manuscripts of the Hebrew Bible, including Aleppo and Leningrad, as well as in some Sephardi manuscripts from the thirteenth century. See Dukan, La Bible hébraïque, 49.

32 Maimonides, Mishne Torah: Sefer Ahavah, Hilkhot Sefer Torah, chap. 8; Kellner, The Code of Maimonides: Book Two; The Book of Love, 97. 
These practices are not mandatory and failing to follow them does not make a scroll faulty for liturgical purposes. In fact, medieval codices of the Hebrew Bible present divergent traditions, and sometimes these practices are not followed at all. However, they will often be observed in the copy of Bible codices as if they were as important as other requirements needed to make a scroll suitable for the synagogue service. In Bible codices that adhere to them, these additional scribal practices will have repercussions for the page layout.

\section{A New Spatial Unit - the Page}

When we open a medieval codex of the Hebrew Bible and we compare it to a Torah Scroll, the thing that strikes us most is something that is generally found in the codex but not in the Torah Scroll - the vocalization of the consonantal text (Heb., nikkud), the cantillation marks (Heb., țe'amim), and, frequently, the paratext in micrography in the margins surrounding the biblical text, generally called the Masorah. ${ }^{33}$ Both the Masorah and the graphical innovations that developed in order to ensure that the text was read and transmitted correctly (vocalization and cantillation marks) were gradually adopted over a period of several centuries ${ }^{34}$ that coincides roughly to the period in which Judaism adopted the codex. The tradition of copying Torah Scrolls for liturgical use, which was firmly established much earlier and codified in the Talmud, did not provide the most favorable conditions for incorporating these elements into scrolls, since the prescriptions of the halakhah (Jewish religious law) were very strict in this regard. Nonetheless, the new codex format was not subject to these prescriptions since it had no liturgical

33 Yeivin, Introduction to the Tiberian Masorah, § 63 (p. 34), defines the Masorah as "the collected body of instructions used to preserve the traditional layout and text of the Bible unchanged." It is traditionally believed that the writing and compiling of the Masorah ended in the tenth century, although it is now being debated whether the copyists of the Masorah after that date limited themselves to merely copying it uncritically and without innovations. The compilers and, to a certain degree, the authors of this body of instructions are called Masoretes. The bibliography on the Masorah and its study is vast, and therefore, besides Yeivin, who was cited previously, I will mention here only the most-general manuals: Page H. Kelley, Daniel S. Mynatt, and Timothy G. Crawford, The Masorah of Biblia Hebraica Stuttgartensia: Introduction and Annotated Glossary (Grand Rapids, Michigan: William Beerdmans Publishing Company, 1998); Elvira Martín Contreras and Guadalupe Seijas de los Ríos-Zarzosa, Masora: La transmisión de la tradición de la Biblia hebrea, Instrumentos para el estudio de la Biblia 20 (Estella: Verbo Divino, 2010).

34 Sixth-ninth centuries, approximately. See Sáenz-Badillos, A History of the Hebrew Language, $\S 4.1$ (p. 77); Ernst Würthwein, The Text of the Old Testament (London: SCM Press, 1979), 21, pushes the date for the beginning of this activity back to the fifth century. 
function, and even if it did, it was at least not used exclusively for this purpose. ${ }^{35}$ Thus, very early on, the Masorah and the graphical innovations for vowels and cantillation marks found a place in the codices of the Hebrew Bible.

The new format made it possible to design a text layout without the constraints imposed by liturgical prescriptions, and there were limitless possibilities for the page layout as well, since it did not have to conform to the scroll's arrangement into columns. Nonetheless, as was already mentioned, many of the requirements that were obligatory for scrolls were also conformed to in codices, to varying degrees. And the arrangement of the text into columns, as was done in scrolls, was also largely observed in codices. ${ }^{36}$

In their transposition to the codex, the columns of Torah Scrolls had to be adapted to the space on the page, which is why the vast majority of Bibles use a page layout consisting of either two or three columns per page - depending on the tradition, the size of the codex and letter size. ${ }^{37}$ In the copying of scrolls, the number of columns per sheet into which the scrolls are divided is governed by the Talmud, which states that this number must be between three and eight. ${ }^{38}$ Emmanuel Tov has shown that this was already the case in the Dead Sea Scrolls, save a few exceptions, with three or four columns being the most common. ${ }^{39}$ A codex with either two or three columns per page, when lying open - a two-page spread being the basic visual unit of a medieval manuscript - would have four or six columns, which is within the parameters established by the Talmud for a sheet in scrolls. The width of a column is also prescribed in the Talmud, though this can vary depending on the letter size and the number of columns that are copied on each sheet. ${ }^{40}$ According to Michèle Dukan, the width of the columns in Torah

35 Some rabbis believed that it was acceptable to read the Torah from a codex for liturgical purposes, especially if a community did not have a Torah Scroll. See Dukan, La Bible hébräque, 40-41.

36 Codices were also copied with the text of the Bible running the entire width of the text block (in a single column). There are several extant examples and many Geniza fragments of this kind of Bible, which was probably more common in small-format codices intended for individual daily use, often lacking the Masorah. See esp. the catalogue of the Bible fragments in the Geniza, M.C. Davis, H. Knopf, and Ben Outhwaite, Hebrew Bible Manuscripts in the Cambridge Genizah Collections, 4 vols. (Cambridge: Cambridge University Press, 1978-2003).

37 The oldest Eastern codices - including Aleppo, Leningrad, and London, British Library, MS Or. 4445, dated 920-50 CE - often arrange the text in three columns per page. This tradition was also followed in European codices, though the two-column layout was widely used as well.

38 b. Menah. 30a, y. Meg. chap. 1.71c-d, Massekhet Soferim chap. 2.10.

39 Tov, Scribal Practices, 80-81.

40 b. Menah. 30a: "Our Rabbis taught: A man should use sheets [of parchment] which contain from three to eight columns; he should not use one which contains fewer columns or more. And he should not put in too many columns for it would look like an epistle, nor too few columns for 
Scrolls from the Islamic period ${ }^{41}$ ranges from $60 \mathrm{~mm}$ to $110 \mathrm{~mm}$, with an average of $85 \mathrm{~mm} .{ }^{42}$ This variation, together with the use of the margins in the design of the mise en page - and moreover, as we have seen, the option of copying two or three columns per page - made it possible for codex scribes to adapt the columns to the space on the page without any great difficulty, in accordance with their individual way of organizing the page layout.

However, the columns in the poetic sections of the Bible are much more standardized. As we have seen, the Talmud establishes norms for the arrangement of these sections, as well as the words that have to go at the beginning of each line. We have also seen how Maimonides adopts other traditions that add new norms for how the text of the poetic sections should be copied. Although following these other norms was not mandatory, they nonetheless became common in Torah Scrolls. Thus, the columns with the poetic sections of the Pentateuch (the Song at the Sea and the Song of Moses) have a different width than the rest of the scroll, generally equivalent to one and a half columns.

Using the data provided by Dukan on column width in Torah Scrolls we can calculate that, in the Islamic period, a column measuring approximately $130 \mathrm{~mm}$, on average, would be required to copy the Song at the Sea. Of course, each scroll has specific measurements that do not necessarily coincide with that number, but the average gives us an idea of the available width for each line of the Song of the Sea to be copied using the same letter size, text density, and spacing between words as were used in the rest of the text, all the while respecting the requirements of the text layout, especially the requirement that each line begin with a particular word.

Keeping in mind the rules given by Maimonides that were mentioned above, a column with the Song at the Sea must have the following structure (Fig. 5): The column must start with the word הבאים ("that came,” Exod 14:28), in accordance with the rule. The next four lines before the beginning of the poem must also start with the prescribed words (ביבשה, יהוה, מת, במצרים, respectively). The poem itself (Exod 15 :1-19) must take up thirty lines, as we have seen. Following the poem, the next five lines of text also must begin with the prescribed words (ותקח, אחריה, סוס, ויצאו, ויבאו, respectively), which makes a total of 42 lines for the whole section, since before and after the poem there has to be a blank line. ${ }^{43}$

the eyes would wander, but [the width of the columns should equal] the word le-mishpehotekhem (למשפחותיכם) written three times." See also Yeivin, Introduction to the Tiberian Masorah, § 78 (p. 44). 41 Produced mostly in Egypt and the Near East between the tenth and the thirteenth centuries. 42 Dukan, La Bible hébraïque, table 6, p. 33.

43 In fact, there is a tendency in Pentateuch scrolls from the Islamic period for the number of lines per column to be 42 in the entire scroll, enabling the arrangement of the Song at the Sea 
LBP 1

LBP 2

LBP 3

LBP 4

LBP 5

[Blank line]

Line 1

Line 2

Line 3

Line 4

Line 5

Line 6

Line 29

Line 30

[Blank line]

LAP 1

LAP 2

LAP 3

LAP 4

LAP 5

Fig. 5: Layout of The Song at the Sea; LBP: Line before the poem; LAP: Line after the poem.

in one single column, with the five lines of text preceding and following the poem in the same column. Some rabbis considered the number 42 to have special significance since it is the sum of the number of days during which the Torah was given to Moses (40) plus the number of the tables of the law (2). See Dukan, La Bible hébraïque, p. 29, n. 26, and table 6, p. 33. The importance of the number 42 was carried over into the codex. Some Bible codices have a page layout with 21 
Thus, the specific regulations for the Song at the Sea establishes the exact text in each of the thirty lines that make up the poem, along with the five lines of text that precede it, and the five lines that follow it. These lines before and after, in addition to the first line of the poem - which, according to Maimonides, is the only one that does not have any blank spaces - are what dictate the width of the poem in its entirety, as long as the norms are observed. As has been noted, the column containing the Song at the Sea is generally wider than an ordinary column, but too narrow to occupy the space of a complete page in a codex of medium size. In addition, the 42 lines that make up the poem's column are often too many to be copied in one column on a single page of a codex. As a result, scribes who followed these specifications were obliged to devise new strategies for creating a page layout that would maintain the tradition while simultaneously producing a graphically balanced and aesthetically pleasing page.

As can be easily imagined, these copying traditions posed a challenge to scribes, which was dealt with in a variety of ways. In MS Paris, BnF, Hébreu 29 (Fig. 6), ${ }^{44}$ the scribe opted to use a column width that is the same as the length of the lines that precede the poem, and this length is determined by the amount of text that is prescribed and by the letter size used in copying the codex. Since the width of the page's text block is larger, ${ }^{45}$ the scribe designed the page layout to accommodate a supplementary column with non-poetic text that precedes the בי"ה שמ"' (that came,” Exod 14:28). In this way, the scribe follows the הבאים word rule and copies the requisite amount of text in each line, without needing to have recourse to other strategies to manage the text.

lines, half a 42-line column, allowing the complete poem of the Song at the Sea to be arranged symmetrically on two facing pages. See Dukan, La Bible hébraïque, 52.

44 Castile? Approx. 1470-80, 3 cols., 224 x 182 mm. See Hermann Zotenberg, Manuscrits orientaux: Catalogues des manuscrits hébreux et samaritains de la Bibliothèque impériale (Paris: Imprimerie impériale, 1866), no. 29; Javier del Barco, Bibliothèque nationale de France: Hébreu 1 à 32; Manuscrits de la bible hébraïque, Manuscrits en caractères hébreux conservés dans les bibliothèques publiques de France 4 (Turnhout: Brepols, 2011), 188-94; Gabrielle Sed-Rajna and Sonia Fellous, Les manuscrits hébreux enluminés des bibliothèques de France, Corpus of illuminated manuscripts 7, Oriental series 3 (Leuven: Peeters, 1994), no. 36; Katrin Kogman-Appel, Jewish Book Art between Islam and Christianity: The Decoration of Hebrew Bibles in Medieval Spain, The Medieval and Early Modern Iberian World 19 (Leiden: Brill, 2004), 218-19.

45 By "text block" I mean the space on the pages of a codex that is reserved prior to copying for a certain text. There is almost always a fixed proportion between text block and page margins, which varies from codex to codex depending on codex size and cultural and regional traditions; see Colette Sirat, Writing as Handwork: A History of Handwriting in Mediterranean and Western Culture, Bibliologia. Elementa ad librorum studia pertinentia 24 (Turnhout: Brepols, 2006), 169-75. 


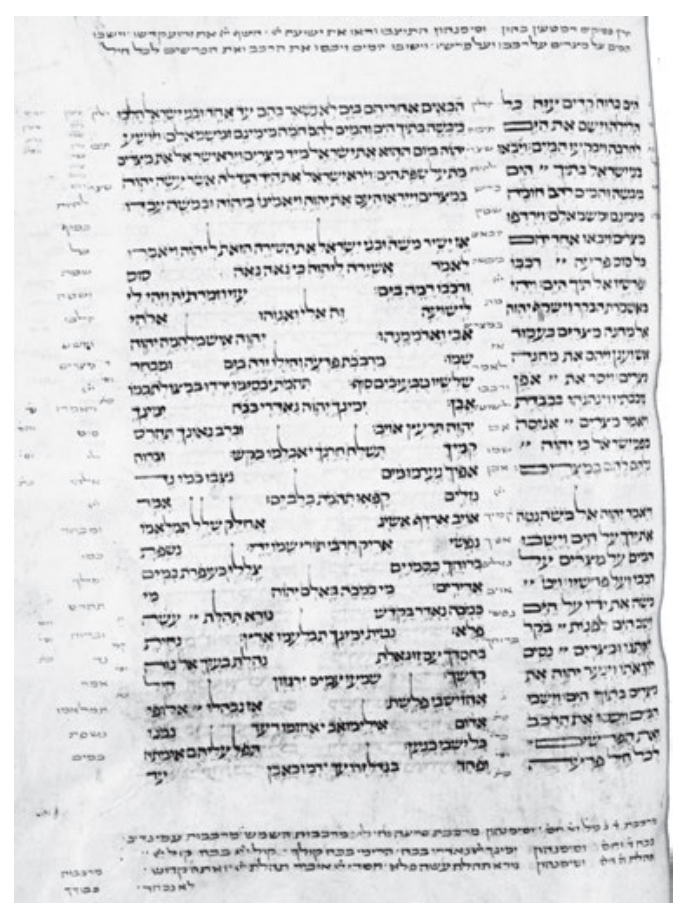

Fig. 6: Paris, BnF, Hébreu 29, fol. 50r.

In MS Paris, BnF, Hébreu 24 (Fig. 7), ${ }^{46}$ the copyist also kept the column width the same as the length of the lines that precede the poem. However, in this case, the choice was made to design the page layout in such a way that the column containing the poem would be positioned in the middle of the page. ${ }^{47}$ The resulting

46 Castile? Approx. 1250-1300, 3 cols., 293 x 251 mm. See Zotenberg, Catalogues des manuscrits hébreux et samaritains, no. 24; Del Barco, Bibliothèque nationale de France: Hébreu 1 à 32, 15053; Sed-Rajna and Fellous, Les manuscrits hébreux enluminés des bibliothèques de France, no. 21; Michel Garel, D’une main forte: manuscrits hébreux des collections françaises (Paris: Seuil, Bibliothèque nationale, 1991), no. 38.

47 Moreover, the copyist took into account the total number of lines occupied by the poem and preceding and following it (42) and fit half of them (21) on each of two facing pages. The result is thus a symmetrical and aesthetically balanced double page, with the book lying open, presenting the Song at the Sea by itself according to Maimonides's prescriptions. This tradition can also be found in other Sephardic codices. See Javier del Barco, "Shirat ha-Yam and Page Layout in Late Medieval Sephardi Bibles," in Sephardic Book Art of the 15th Century, ed. Luís U. Afonso and Tiago Moita, Studies in Medieval and Early Renaissance Art History (Turnout: Harvey Miller, 2020): 107-20. 


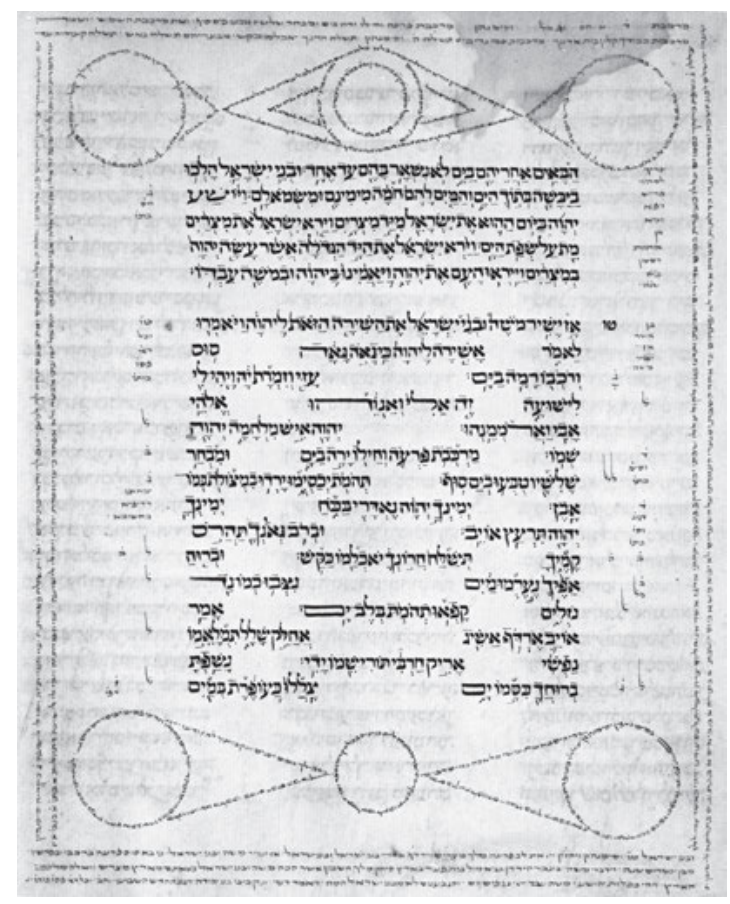

Fig. 7: Paris, BnF, Hébreu 24, fol. 37v.

margins, which are much wider than in the rest of the manuscript, give the copyist space to include sections of the Masorah adopting figurative forms.

In MS Paris, BnF, Hébreu 28 (Fig. 8), ${ }^{48}$ different strategies were adopted. The copyist copied the five lines preceding the poem according to the tradition transmitted by Maimonides, such that each of these lines begins with the prescribed word. The resulting width of these lines is, therefore, the width that the entire poem should have. However, we can see that this is not what was done. The text of the poem, which is recognizable because it has been arranged according to the brick pattern model, was copied by adjusting the width to the size of the text block, which is larger than that of the lines preceding the poem. When copying

48 Iberian Peninsula, 1344, 2 cols., 218 x 172 mm. See Zotenberg, Catalogues des manuscrits hébreux et samaritains, no. 28; Del Barco, Bibliothèque nationale de France: Hébreu 1 à 32, 182-185; Colette Sirat and Malachi Beit-Arié, Manuscrits médiévaux en caractères hébraïques: portant des indications de date jusqu'à 1540 - Otsar kitve-yad 'ivriyim mi-yeme-ha-benayim: betsiyune ta'arikh 'ad shenat 5300, vol. 1. (Paris and Jerusalem: Centre National de la Recherche Scientifique, Ha-Akademyah ha-Le'umit ha-Yisra'elit le-Mada'im, 1972), no. 30; Sed-Rajna and Fellous, Les manuscrits hébreux enluminés des bibliothèques de France, no. 136. 


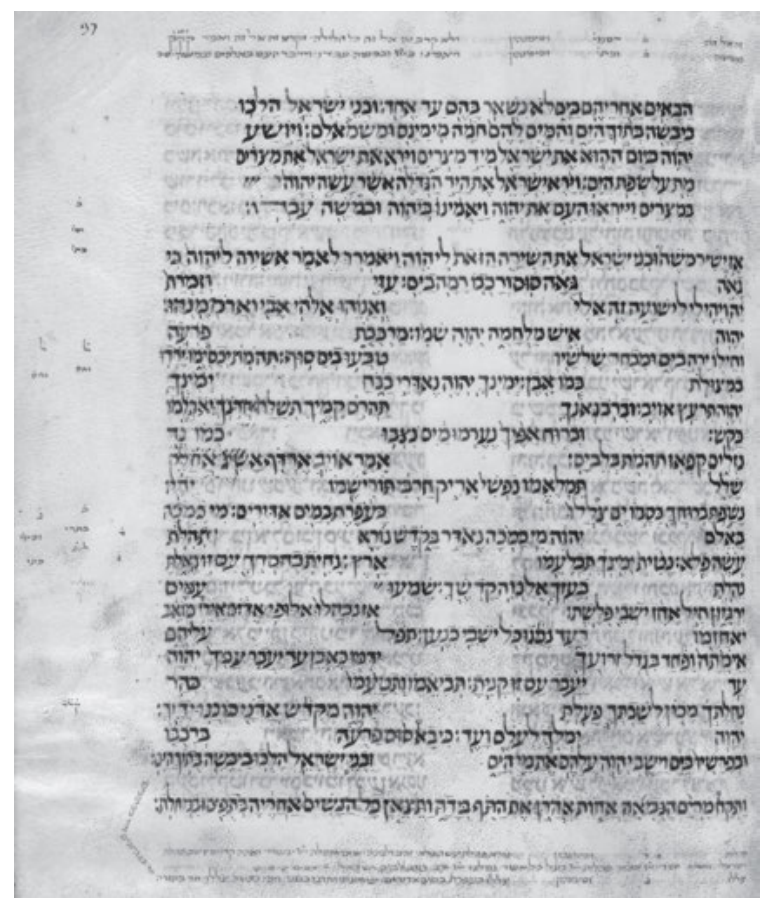

Fig. 8: Paris, BnF, Hébreu 28, fol. 37v.

the poem, the copyist opted to use the entire width of the page provided by the text block, which meant that he was forced to disregard the prescribed words for the beginning of each line of the poem. And this meant, in turn, that each line contains more text than would have been the case if the prescribed first words had been adhered to. Thus, the complete poem occupies only 21 lines, compared to the 30 that it would occupy if Maimonides's norms had been followed. This also made it possible for the whole poem to be copied on a single page, in such a way that the unit of meaning (the poem) coincides with the smallest unit of textual organization (the page). However, it should be pointed out that the scribe copied the text of the poem using the brick pattern arrangement, so that it would be visually recognizable and have at least the appearance of a poetic text.

In MS Paris, BnF, Hébreu 19 (Fig. 9), ${ }^{49}$ we observe strategies for managing the text that are different from the ones above. As in the preceding case, the scribe

49 Northern France? Approx. 1275-1325, 3 cols., 456 x 337 mm. See Zotenberg, Catalogues des manuscrits hébreux et samaritains, no. 19; Del Barco, Bibliothèque nationale de France: Hébreu 1à 32, 106-9; Sed-Rajna and Fellous, Les manuscrits hébreux enluminés des bibliothèques de France, no. 64. 


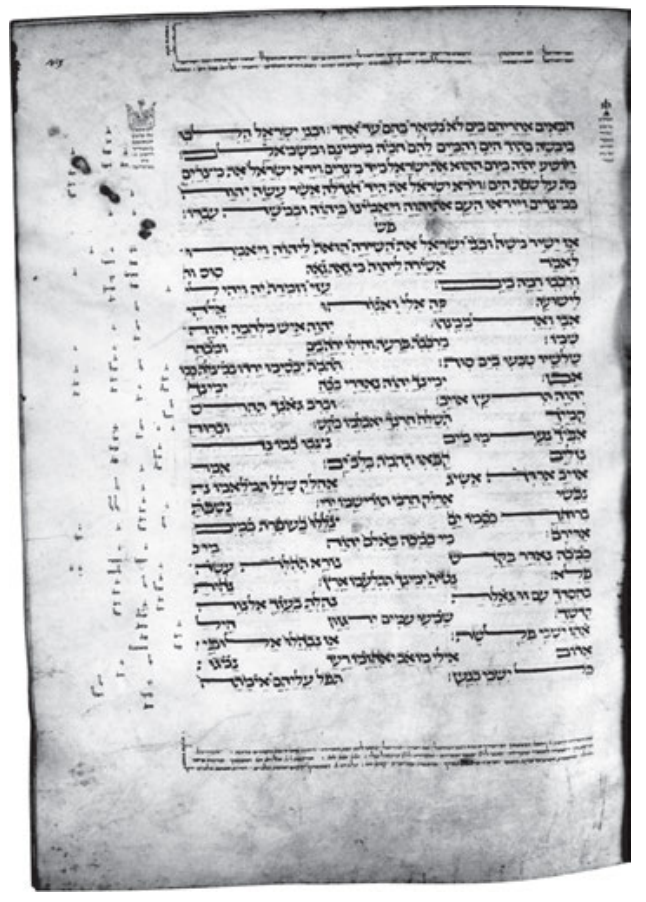

Fig. 9: MS Paris, BnF, Hébreu 19, fol. 49r.

copied the five lines that precede the poem following the tradition transmitted by Maimonides, and each of them begins with the prescribed words except line $3 .{ }^{50}$ Below, the scribe fit the text of the poem on 30 lines, each of which also begins with the prescribed words. The resulting text block is of the same width as the rest of the manuscript. That is, the page does not have margins that are any wider than usual. To achieve this page layout, the scribe had to resort to using stretchedout or elongated letters, a common device used by Jewish scribes to manage line length. ${ }^{51}$ Elongated letters are used in this example both in the five lines that precede the poem and in the lines of the poem itself, so that the text occupies the entire width of the text block without leaving additional space in the side margins.

50 The Talmud and Maimonides both prescribe that line 3 should start with the word ("God"), from ויושע יהוה ("Thus God saved,” Exod 14:30). Here, this line starts with therd that comes before it in the same verse.

51 Using stretched-out or elongated letters is one of the devices that Jewish scribes used to make columns justified on the left. See Malachi Beit-Arié, Unveiled Faces of Medieval Hebrew Books: The Evolution of Manuscript Production - Progression or Regression? (Jerusalem: Magnes Press, 2003), chap. 2, “Copying Dynamics: Line Management," 32-48. 
Nonetheless, the variety of forms taken by Hebrew Bible codices, especially during the late Middle Ages, ${ }^{52}$ meant that scribes had to make more and more decisions about the text layout in the manuscript as a whole and about the page layout to adopt for the specific pages on which the Song at the Sea and other poetic sections were copied. For example, beginning in the thirteenth century, Hebrew Bible codices started to appear in Ashkenaz that had, in addition to the Hebrew text, the Aramaic paraphrase, or Targum, and Rashi's commentary (Shelomo ben Yitzhak de Troyes, 1040-1105)..$^{53}$ This accretion of texts would have been unthinkable for copies of Pentateuch scrolls, but the codex format could be adapted to new functions, new modes of reading, and different exegetical traditions. Thus, both the form and the function of the Hebrew Bible codex gradually moved away from those of Pentateuch scrolls.

In MS Paris, BnF, Hébreu 8 (Fig. 10), ${ }^{54}$ the scribe copied the Hebrew text and its paraphrase in Aramaic for the entire Pentateuch. As a text layout strategy, the choice was made to copy the two texts verse by verse, using the same letter type and size for both. As a result, it is not possible to differentiate one from the other by visual means. For the page on which the Song at the Sea appears, the scribe maintained this same text layout strategy in the poem, such that following each verse in Hebrew is the corresponding Aramaic. In order to do this, the scribe gave up on following the prescriptions given by the Talmud and Maimonides. The page does not obey the בי"ה שמ"rule, the text preceding the poem is not arranged into five lines beginning with the prescribed words, and the lines of the poem itself do not start with the prescribed words either. The scribe also failed to follow Maimonides's instructions regarding the spaces that there should be in each line of the poem (one or two), and due to the considerable page width (320 mm), the choice was made to insert two or three spaces in each line. In the end, the only

52 For a preliminary typology and genres of the medieval Hebrew Bible, see David Stern, "The Hebrew Bible in Europe in the Middle Ages: A Preliminary Typology,” Jewish Studies: An Internet Journal 11 (2012): 235-322; and David Stern, The Jewish Bible: A Material History, Samuel and Althea Stroum Lectures in Jewish Studies (Seattle: University of Washington Press, 2017), 88-131. I am presently preparing a monograph about form and function in medieval manuscripts of the Hebrew Bible in the late Middle Ages.

53 See Stern, "The Hebrew Bible in Europe," 71-77; Stern, The Jewish Bible, 119-26; and Javier del Barco, "The Ashkenazi Glossed Bible," The Polonsky Foundation Catalogue of Digitised Hebrew Manuscripts, Articles (blog), 2016, http://www.bl.uk/hebrew-manuscripts/articles/ theashkenazi-glossed-bible.

54 Ashkenaz, 1300-1305, 3 cols., 447 x 319 mm. See Zotenberg, Catalogues des manuscrits hébreux et samaritains, no. 8; Del Barco, Bibliothèque nationale de France: Hébreu 1 à 32, 54-59; Sirat and Beit-Arié, Manuscrits médiévaux en caractères hébraïques, vol. 1, no. 28; Sed-Rajna and Fellous, Les manuscrits hébreux enluminés des bibliothèques de France, no. 72. 


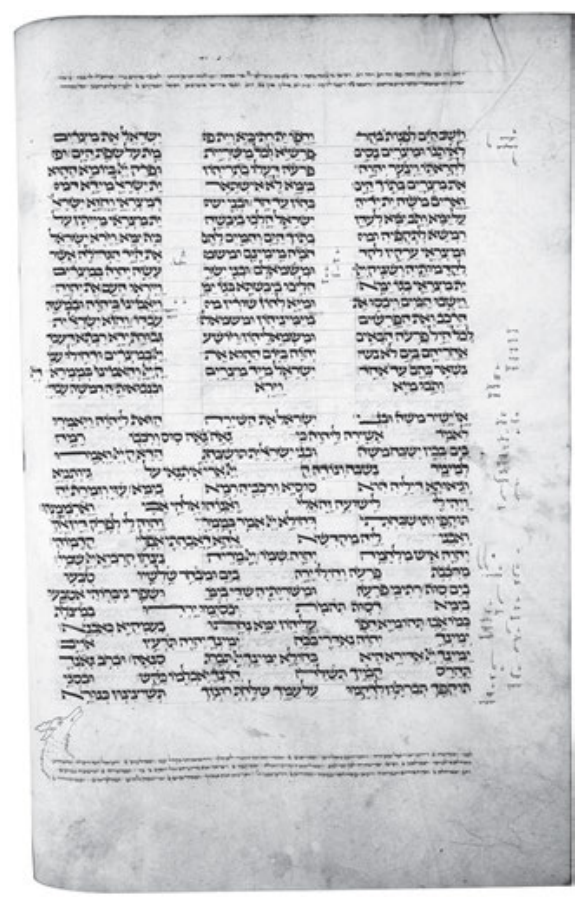

Fig. 10: MS Paris, BnF, Hébreu 8, fol. 75v.

device used by the scribe to distinguish the poem from the rest of the text is the brick pattern arrangement, used for both the Hebrew text as well as the paraphrase in Aramaic.

The manuscripts from which the examples we have looked at up to now are taken come from different geo-cultural areas (Sepharad and Ashkenaz) and cover a broad chronological range, from the end of the thirteenth century to the end of the fifteenth. They do not represent, therefore, tendencies or characteristics that can be attributed to a particular time in a particular place; rather, they provide an initial overview of the repertoire of strategies that Jewish scribes used in the late Middle Ages to accommodate a text, the Song at the Sea, that had to comply with a series of specific requirements that were part of the text layout of the Bible in the scroll format. How these strategies developed and spread, the contexts in which they were used, and to what degree they succeeded and helped to create models for copying codices of the Hebrew Bible are questions that have been largely ignored up to now. ${ }^{55}$

55 Dukan, La Bible hébraïque, pp. 44-54, makes a preliminary attempt to deal with the variety of ways that the Song at the Sea is arranged in Eastern and Sephardi codices prior to 1280, and 


\section{Teaching the Tradition: From Codex to Scroll}

It was mentioned earlier that Maimonides copied a Torah Scroll taking as a model a codex that was famous in Egypt for its authoritativeness and fidelity to tradition. What is interesting about this quotation from Maimonides about the fact of copying from a model is that it reflects what seems to have become a common practice after the adoption of the codex as a valid format for copying the text of the Bible. It became customary at that point to copy codices and scrolls consulting a revised and authoritative codex (sefer muggah), ${ }^{56}$ that is, a model or exemplar codex for the correct copy of the biblical text according to the halakhah. Although this is something that has not been much studied in late medieval codices, the Masorah in some of these codices includes very precise instructions regarding things that relate specifically to the layout of the biblical text. These instructions, copied into the margins of the codices, must have served in many cases as reminders, or a sort of instruction manual, for scribes who had to copy a Torah Scroll. It is difficult to know whether any of these codices served specifically and exclusively as exemplar codices, since we know very little at this point about the specific function or functions of the different types of medieval codices of the Hebrew Bible. Nonetheless, it is common in Bible codices with Masorah to find references to certain readings and spellings that come from the same group of codices, including the famous Hilleli codex, the Yerushalmi codex, the Zambuki codex, and others. ${ }^{57}$ These doubtless must have served as exemplar codices for copying other codices, and they were possibly used for copying Torah Scrolls as well.

Other manuscripts whose margins have precise instructions about the layout of the biblical text might also have served as exemplar codices, though they may have been used in other contexts as well. This was possibly the case of MS Paris, BnF, Hébreu $65 .^{58}$ This codex of the Hebrew Bible consistently indicates the differences between Maimonides and the work called Sefer tagi relating to the open and closed sections of the Pentateuch. Maimonides and Sefer tagi transmit different

to establish some copying traditions. See also Del Barco, "Shirat ha-Yam and Page Layout in Late Medieval Sephardi Bibles," for a preliminary study of the arrangement of the Song at the Sea in the Sephardi tradition.

56 On the term sefer muggah, see Yeivin, Introduction to the Tiberian Masorah, § 152 (p. 138), and Kelley, Mynatt, and Crawford, The Masorah of Biblia Hebraica Stuttgartensia, s. v. מוגה, p. 133.

57 On these references, see Ginsburg, Introduction to the Massoretico-Critical Edition of the Hebrew Bible, 429-41; Yeivin, Introduction to the Tiberian Masorah, § 152 (p. 138); and more recently, M. Teresa Ortega Monasterio, "Los códices modelo y los manuscritos hebreos bíblicos españoles,” Sefarad 65 (2005): 353-83.

58 Northern Italy, around 1400, 1 col., 335 x 224 mm. See Zotenberg, Catalogues des manuscrits hébreux et samaritains, no. 65; Garel, D’une main forte, 79. 
traditions regarding the starting and ending points and whether the sections are open or closed within each pericope of the Pentateuch, and all these discrepancies are indicated in the margins of MS Paris, BnF, Hébreu 65. This kind of information is relevant for copying Torah Scrolls and in itself might suffice for this manuscript to be defined as an exemplar codex. However, there are other marginal notes that would seem to corroborate this possible function of the codex, in particular some that specify how certain features of the text layout should appear in Torah Scrolls, which is something that is not always specified in medieval codices of the Hebrew Bible. Some of these annotations are the following:

- On folio $201 \mathrm{v}$, one of the cases where there is a prescribed word that must be at the beginning of the column (according to the rule) is indi-

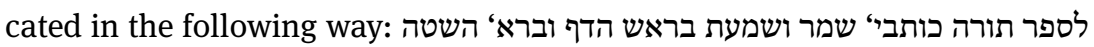
("[Instruction] for Sefer Torah: we write 'Observe and obey' (Exod 34:11) at the beginning of the sheet and at the beginning of the line").

- On folio 223r, the same instruction is given regarding ואעידה ("and I will call to witness,” Deut 31:28), which precedes the Song of Moses, also according to the rule. Here, as in Maimonides, the prescribed words at the beginning of each of the six lines of text that precedes the Song of Moses are also indicated, in the following way: לספ' תורה כותבי' לפני שירת האזינו ו' ראשי

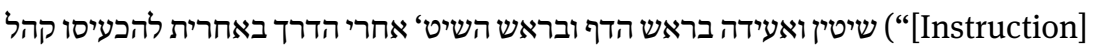
for Sefer Torah: we write before the poem 'Give ear' (the Song of Moses) [the following] six beginnings of lines: 'and I will call to witness' at the beginning of the sheet and at the beginning of line, 'after,' 'the way,' 'in the latter,' 'to provoke him to anger,' and 'the congregation' [at the beginning of the line]”).

- On folio 226r, there is an annotation about a tradition, also transmitted by Maimonides, for copying Torah Scrolls, regarding the last line of the Pentateuch ${ }^{59}$ :

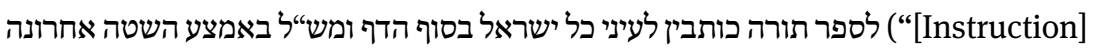
for Sefer Torah: we write 'in the sight of all Israel' (Deut 34:12) at the end of the sheet, and also in the middle of the last line"). Unlike the other two annotations, this instruction is not reflected in the way this codex dealt with the verse in question. Indeed, the fact that this instruction is provided here but is not applied to the copy of the text confirms that it is not describing how the text was copied in this codex but how it should be copied in a Torah Scroll. Thus, we can affirm that this Bible functions as a model or exemplar codex.

59 Maimonides, Mishne Torah: Sefer Ahavah, Hilkhot Sefer Torah, chap. 7.7; Kellner, The Code of Maimonides: Book Two; The Book of Love, 96. 
These and other indications in this manuscript that address text layout must have been used as an instruction manual by scribes copying Torah Scrolls. This is true as well of MS Paris, BnF, Hébreu 19, mentioned above, where among other things we find indications about the text layout of the five lines that precede the Song at the Sea. In the margins of folio 49r there are two highly precise annotations about the prescriptions that govern the copying of these lines. In the right margin we read: הבאים בראש עמוד בספר תורה וסי' ביה שמו ("[the word] 'that came' (Exod 14:28) [should be written] at the beginning of the column in a Torah Scroll, and the [mnemonic] indication is בי"ה שמ"ה שמ"i rule]"). In the left margin, the note specifies: והן כתובין בה' שיטין הבאים ביבשה ויושע מת במצרים ("And this [text preceding the poem] is copied in five lines [whose beginnings are] 'that came,' 'dry land,' 'thus [God] saved,' 'dead,' and 'upon the Egyptians'”). As noted before, the word at the beginning of line 3 in this manuscript is not יהוה ("God"),

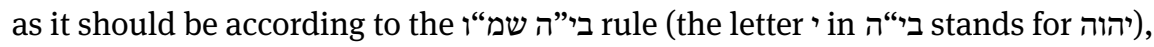
but the preceding word, ויושע. However, the scribe gives the בי"ה שמיה שמיה rule for the copying of Torah Scrolls in the right margin, and seems to find no contradiction in giving also the indication of the first word in line 3 (ויושע) in the annotation in the left margin. That is, the use of the word ויושע at the beginning of line 3 in this case is not due to ignorance of the בי"ה שמ"r rule, but rather perhaps to the use of a local tradition that was different from the dominant tradition. It remains to be seen whether this tradition is documented in other Ashkenazi codices and, more significantly, if it was followed in the coping of Ashkenazi Torah Scrolls, which might be the focus of further research in the future.

On folio $49 \mathrm{v}$ of this same manuscript we find similar annotations about line 30 of the Song at the Sea and about the five lines that follow the poem. In the right margin, we read: מי בראש שיטה ("[the word] 'waters' at the beginning of [this] line [which is line 30 in the poem]"). ${ }^{60}$ On the same folio, in the blank space of the open section after the five lines that follow the poem, we read the following indication: אלו חמשה ראשי שיטין ותקח אחריה סוס ויצאו ויבאו "These are the words at the beginning of the five lines [after the poem]: 'took,' 'after her,' 'the horse,' 'they went out,' and 'and when they came'”). Thus, in this manuscript we find precise instructions for copying the lines that precede and follow the Song at the Sea according to tradition, as well as for copying line 30 of the poem, about whose first word there were different traditions, as was mentioned above.

The cases that we have just seen indicate, in my opinion, that there was a close relationship between codices of the Hebrew Bible and Torah Scrolls when

60 This is the prescribed word according to Massekhet Soferim, which is different from the tradition transmitted by Maimonides. See above. 
it came to copying the latter. This does not necessarily mean that the scribes who made Torah Scrolls copied the text directly from a codex but rather that they probably used certain codices as study manuals for copying and as reference and revision guides for both the text and the text layout. The fact that these indications do not appear in all Bible manuscripts that also contain the Masorah, but only in certain codices of the Hebrew Bible, thus seems to point to the function that these codices may have had as model or exemplar codices in the communities in which they were copied and used.

\section{Conclusion}

As was recalled at the beginning of this chapter, the period of transition from the scroll - whether vertical or horizontal - as the only format for Hebrew texts to the codex as the main format had to have been more prolonged than what has traditionally been maintained. During this lapse of time, the adoption of the codex brought with it a distribution of functions between the scroll and the codex, and as those functions belonging to the former decreased, those belonging to the latter increased. This process of distributing functions must have happened gradually, until the scroll was finally relegated almost exclusively to the function of the liturgical reading of the Pentateuch and Esther in the synagogue, ${ }^{61}$ which is the role that it continues to have still today. Meanwhile, the codex, because of its ease of use, assumed the rest of the functions that had previously been performed by the scroll and gained priority in all spaces except for the synagogue.

Therefore, codices were copied for daily reading, for studying, for carrying around, as gifts, as works of art, and for other purposes. We can discern some of these functions from the features in Bible codices, as we were able to see with the exemplar codices. However, this does not mean that any given codex did not have multiple functions or that these did not change over time. An in-depth study of the possible functions of Bible codices relative to their formal characteristics is then an important direction for future research.

In the end, Judaism's adoption of the codex did not mean that it abandoned the scroll as a medium for reading and transmitting the text of the Bible. The

61 The reading of the weekly pericope of the Pentateuch from a Torah Scroll continues to be one of the most important moments in the liturgy of the Sabbath and, to a lesser degree, on Mondays and Thursdays, when an excerpt from the pericope corresponding to the following Sabbath is read. Likewise, the reading of the book of Esther from a scroll continues to be the most important moment in the liturgy for the Purim holiday. 
relationship between the two formats underlies the dynamics of text layout transformation, as has been shown in some examples of Bible codices. It also explains the marginal notes that we find in some codices, which provide precise specifications for copying special sections of the Pentateuch, according to traditional scribal practices. A systematic study of medieval and early modern Torah Scrolls, which still remains to be undertaken, will be able to shed light on the impact that the adoption of the codex had on these scrolls and will provide more details about the interaction and coexistence of the two different formats.

\section{Bibliography}

Andrist, Patrick, Paul Canart, and Marilena Maniaci. La syntaxe du codex: Essai de codicologie structurale. Bibliologia: elementa ad librorum studia pertinentia 34. Turnhout: Brepols, 2013.

Azcárraga, María Josefa de. "Las 'ôtiyyôt gedôlôt en las compilaciones masoréticas." Sefarad 54/1 (1994): 13-29.

Beit- Arié, Malachi. Hebrew Codicology: Tentative Typology of Technical Practices Employed in Hebrew Dated Medieval Manuscripts. Paris: Institut de recherche et d'histoire des textes, 1977.

Beit- Arié, Malachi. Unveiled Faces of Medieval Hebrew Books: The Evolution of Manuscript Production - Progression or Regression? Jerusalem: Magnes Press, 2003.

Beit-Arié, Malachi, R. A. May, and Adolf Neubauer. Catalogue of the Hebrew Manuscripts in the Bodleian Library: Supplement of Addenda and Corrigenda to Vol. 1 (A. Neubauer's Catalogue). Oxford: Clarendon Press, 1994.

Beit- Arié, Malachi, Colette Sirat, and Mordechai Glatzer. Codices hebraicis litteris exarati quo tempore scripti fuerint exhibentes - Otsar ha-mitshafim ha-ivriyim: kitve-yad bi-khetav ivri mi-yeme ha-benayim be-tsiyune ta'arikh. Vol. 1, Jusqu'à 1020. Monumenta paleographica Medii Aevi. Series hebraica. Turnhout: Brepols, 1997.

Cohen, Abraham, ed. Hebrew-English Edition of the Babylonian Talmud: Minor Tractates. London: Soncino Press, 1948.

Davis, M.C., H. Knopf, and Ben Outhwaite. Hebrew Bible Manuscripts in the Cambridge Genizah Collections. Cambridge University Library Genizah Series 2. Cambridge: Cambridge University Press, 1987.

Del Barco, Javier. “The Ashkenazi Glossed Bible.” The Polonsky Foundation Catalogue of Digitised Hebrew Manuscripts. Articles (blog), 2016. http://www.bl.uk/ hebrew-manuscripts/articles/the-ashkenazi-glossed-bible.

Del Barco, Javier. Bibliothèque nationale de France: Hébreu 1 à 32; Manuscrits de la bible hébraïque. Manuscrits en caractères hébreux conservés dans les bibliothèques publiques de France 4. Turnhout: Brepols, 2011.

Del Barco, Javier. "Shirat ha-Yam and Page Layout in Late Medieval Sephardi Bibles." In Sephardic Book Art of the 15th Century, edited by Luís U. Afonso and Tiago Moita, 107-120. Studies in Medieval and Early Renaissance Art History. Turnout: Harvey Miller, 2020.

Déroche, François. Manuel de codicologie des manuscrits en écriture arabe. Études et recherches. Paris: Bibliothèque Nationale de France, 2000. 
Dukan, Michèle. La Bible hébraïque: Les codices copiés en Orient et dans la zone séfarade avant 1280. Bibliologia: elementa ad librorum studia pertinentia 22. Turnhout: Brepols, 2006.

Garel, Michel. D’une main forte: manuscrits hébreux des collections françaises. Paris: Seuil, Bibliothèque nationale, 1991.

Ginsburg, Christian D. Introduction to the Massoretico-Critical Edition of the Hebrew Bible. New York: Ktav Publishing House, 1966.

Kantrowitz, David. The Soncino Talmud (version 3.0.8). Davka Corp. and Judaic Press, 2004.

Kelley, Page H., Daniel S. Mynatt, and Timothy G. Crawford. The Masorah of Biblia Hebraica Stuttgartensia: Introduction and Annotated Glossary. Grand Rapids, Michigan: William Beerdmans Publishing Company, 1998.

Kellner, Menahem, trans. The Code of Maimonides: Book Two; The Book of Love. Yale Judaica Series 32. New Haven: Yale University Press, 2004.

Kogman-Appel, Katrin. Jewish Book Art between Islam and Christianity: The Decoration of Hebrew Bibles in Medieval Spain. The Medieval and Early Modern Iberian World 19. Leiden: Brill, 2004.

Lehmann, Manfred R. "Further Study of the Pe'in Lefufot.” In Proceedings of the Eleveenth Congress of the International Organization for Masoretic Studies (IOMS), Jerusalem, June 21-22, 1993, edited by Aron Dotan, 41-46. Jerusalem: World Union of Jewish Studies, 1994.

Martín Contreras, Elvira, and Guadalupe Seijas de los Ríos-Zarzosa. Masora: La transmisión de la tradición de la Biblia hebrea. Instrumentos para el estudio de la Biblia 20. Estella: Verbo Divino, 2010.

Neubauer, Adolf, and A.E. Cowley. Catalogue of the Hebrew Manuscripts in the Bodleian Library and in the College Libraries of Oxford. 2 vols. Oxford: Clarendon Press, 1886-1906.

Neusner, Jacob, trans. The Talmud of the Land of Israel: A Preliminary Translation and Explanation. Vol. 19, Megillah. Chicago Studies on the History of Judaism. Chicago: The University of Chicago Press, 1987.

Olszowy-Schlanger, Judith. "The Anatomy of Non-Biblical Scrolls from the Cairo Geniza." In Jewish Manuscript Cultures: New Perspectives. Berlin: De Gruyter, 2017.

Olszowy-Schlanger, Judith. "The Hebrew Bible.” In The New Cambridge History of the Bible. Vol. 2, From 600 to 1450, edited by Richard Marsden and E. Ann Matter, 19-40. Cambridge: Cambridge University Press, 2012.

Ortega Monasterio, M. Teresa. "Los códices modelo y los manuscritos hebreos bíblicos españoles." Sefarad 65 (2005): 353-83.

Resnick, Irven M. "The Codex in Early Jewish and Christian Communities." Journal of Religious History 17/1 (1992): 1-17.

Sáenz-Badillos, Ángel. A History of the Hebrew Language. Cambridge: Cambridge University Press, 1996.

Sed-Rajna, Gabrielle, and Sonia Fellous. Les manuscrits hébreux enluminés des bibliothèques de France. Corpus of illuminated manuscripts 7, Oriental series 3. Leuven: Peeters, 1994.

Sirat, Colette. Hebrew Manuscripts of the Middle Ages. Cambridge: Cambridge University Press, 2002.

Sirat, Colette. Writing as Handwork: A History of Handwriting in Mediterranean and Western Culture. Bibliologia. Elementa ad librorum studia pertinentia 24. Turnhout: Brepols, 2006.

Sirat, Colette, and Malachi Beit-Arié. Manuscrits médiévaux en caractères hébraïques: Portant des indications de date jusqu'à 1540 - Otsar kitve-yad 'ivriyim mi-yeme-ha-benayim: 
be-tsiyune ta'arikh 'ad shenat 5300, vol. 1. Paris: Centre National de la Recherche Scientifique, 1972.

Stern, David. "The First Jewish Books and the Early History of Jewish Reading." JQR 98/2 (2008): 163-202.

Stern, David. "The Hebrew Bible in Europe in the Middle Ages: A Preliminary Typology." Jewish Studies: An Internet Journal 11 (2012): 235-322.

Stern, David. The Jewish Bible: A Material History. Samuel and Althea Stroum Lectures in Jewish Studies. Seattle: University of Washington Press, 2017.

Tov, Emanuel. Scribal Practices and Approaches Reflected in the Texts Found in the Judean Desert. STDJ 54. Leiden: Brill, 2004.

Würthwein, Ernst. The Text of the Old Testament. London: SCM Press, 1979.

Yeivin, Israel. Introduction to the Tiberian Masorah. Translated by E. J. Revell. Masoretic studies 5. Missoula, Montana: Scholars Press, 1980.

Zotenberg, Hermann. Manuscrits orientaux: Catalogues des manuscrits hébreux et samaritains de la Bibliothèque impériale. Paris: Imprimerie impériale, 1866. 